Portland State University

PDXScholar

6-10-1992

\title{
Textural Constraints on Effusive Silicic Volcanism: Beyond the Permeable Foam Model
}

\author{
Jonathan H. Fink \\ Portland State University, jon.fink@pdx.edu \\ Steven W. Anderson \\ Arizona State University \\ Curtis R. Manley \\ Arizona State University
}

Follow this and additional works at: https://pdxscholar.library.pdx.edu/geology_fac

Part of the Geology Commons, and the Volcanology Commons

Let us know how access to this document benefits you.

\section{Citation Details}

Fink, J. H., Anderson, S. W., \& Manley, C. R. (1992). Textural constraints on effusive silicic volcanism: Beyond the permeable foam model. Journal of Geophysical Research: Solid Earth (1978-2012), 97(B6), 9073-9083. 


\title{
Textural Constraints on Effusive Silicic Volcanism: Beyond the Permeable Foam Model
}

\author{
Jonathan H. Fink, Steven W. Anderson ${ }^{2}$, and Curtis R. Manley
}

Department of Geology, Arizona State University, Tempe, Arizona

\begin{abstract}
Transitions between explosive and effusive phases of silicic volcanic eruptions have been related either to stratification of volatiles in the source magma body or to the loss of volatiles through the permeable host rock of the conduit. One way to distinguish between these two models is to map and analyze the vesicular and glassy textures found in silicic lava flows. In this paper we present textural observations and isotopic evidence from active and Recent silicic lava flows which show that at least some vesiculation occurs during surface advance of extrusions, after magma has reached the earth's surface. This view is in contrast to the widely promoted "permeable foam" model, which states that all volatiles escape during ascent of the magma, and that all dense glassy material in lava flows forms from the collapse of pumiceous lava, i.e., that silicic lavas emerge as highly inflated foam flows. Such interpretations which claim that silicic lavas are completely degassed upon extrusion, and that all degassing must take place on the time scale of the eruption, neglect several important pieces of evidence, including the presence of obsidian in extremely small domes, and of vesicular zones in the interiors of silicic flows; the copious loss of volatiles through eruption plumes between eruptive phases; and direct observations of surface vesiculation during growth of the Mount St. Helens lava dome. The permeable foam model also implies the unlikely requirement that explosive-to-effusive transitions be associated with an increase in eruption rate. We present a more comprehensive model for the emplacement of silicic extrusions that allows for early gas loss during ascent, as well as late-stage vesiculation. We then discuss how the redistribution of volatiles during surface flow can increase explosive hazards from silicic lavas days, weeks, or months after the lava emerges from the vent.
\end{abstract}

\section{INTRODUCTION}

In the early 1990 s, the growth and explosive collapse of lava domes on volcanoes in several populated areas around the Pacific Rim have drawn popular and scientific attention to the emplacement of silicic magmas. The hazards associated with eruptions of these magmas depend on whether they emerge explosively or effusively. Explosions may both precede and accompany the extrusion of lavas. Many silicic domes overlie deposits of air fall pumice from nearly contemporaneous eruptions. The distal surfaces of older rhyolite flows are commonly covered with explosion craters indicating that high internal pressures may occur in flows that have traveled long distances. Similar high pressures are implied by pyroclastic flows that emerge from the fronts of dacite lava flows and domes, up to a kilometer or more from the vent. Because transitions between pyroclastic activity and lava flows have only rarely been studied, they remain both poorly constrained and controversial. This paper is concerned with how pre-eruption water contents of silicic magma bodies can be inferred from the lava flows they produce, and with the role of such volatiles in controlling ransitions between explosive and effusive eruptions. Until the Inyo and Valles drilling programs in the mid-1980s [Eichelberger et al., 1984, 1985; Goff et al., 1986], most volcanologic studies assumed that the common sequence of initial, explo-

Now a Department of Mathematics, Physical Sciences, and Technology, Black Hills State University, Spearfish, South Dakota.

Copyright 1992 by the American Geophysical Union. sive Plinian eruptions followed by quiet effusions of lava was caused by a stratification of volatiles in the source magma body [e.g., Perret, 1937; Taylor, 1958; Heiken, 1978; Eichelberger and Westrich, 1981; Fink, 1983]. The Inyo drill cores provided the first opportunity to simultaneously view the interiors of a young (550 years old) silicic lava flow, its conduit, feeder dike, and immediately subjacent tephra deposits. Based largely on the Inyo exposures, Eichelberger and his colleagues [Taylor et al., 1983; Eichelberger et al., 1986; Taylor, 1986; Westrichet al., 1988; Swanson et al., 1989] arrived at a new model for silicic lava emplacement which proposes that all such flows and domes reach the surface as highly inflated and permeable pumiceous foams whose volatiles are lost to the country rocks through the walls of their fractured and porous conduits during ascent. This model implies that the water content throughout these lavas should be at or near the 1-atm equilibrium value of $0.1 \mathrm{wt} \%$, that all dense obsidian in a lava flow is derived from pumice by bubble collapse and resorption during flow advance over the ground surface, and that all vesicular zones in silicic extrusions are residual.

These two contrasting models ("volatile stratification" and "permeable foam") have significantly different implications for eruption models and hazards assessment. The stratification model suggests that changes in explosivity and the distribution of volatiles in eruptive products both reflect the original, heterogeneous arrangement of volatiles in the source magma body. In contrast, the foam model implies that magma bodies have a more uniform. volatile distribution, and that observed variations in eruptive behavior and water contents of lavas are controlled by differing permeabilities of conduit wall rocks. The foam model further states that once silicic magma reaches the surface, it is porous and 
permeable, and that since nearly all its volatiles have escaped, its vesicularity can only decrease during surface flow. The model thus ignores formation of heterogeneities in volatile content in the lava flow after extrusion onto the surface; such a process seems necessary to generate gas-rich zones capable of endogenic (postextrusion) explosive decompression at distal locations [e.g., Rose et al., 1977; Fink and Manley, 1989].

Since its original proposal, the permeable foam model has gained acceptance from many petrologists and from volcanologists who focus on explosive processes. Although based only on data from rhyolite flows, the model has been extrapolated to dacite extrusions as well. It was challenged by Friedman [1989], who took particular exception to the idea that water-depleted pumice could weld into obsidian without leaving any microscopic evidence. Eichelberger [1989] countered most of Friedman's objections, and a series of welding experiments were subsequently performed [Westrich and Eichelberger, 1989] to demonstrate that, in fact, it was possible for hot pumice to resorb all vesicles if pressures equivalent to flow depths of $20 \mathrm{~m}$ or greater were maintained.

Any model of magmatic degassing must be consistent with not only the chemical and petrologic details of the system, but with the physical rield evidence as well. Young silicic lava flows in the western United States and Central America are easily visited and inspected, and their surfaces hold many clues about their emplacement. Although the permeable foam hypothesis accounts for certain mineralogic and stratigraphic observations, one of its key limitations has been its neglect of a wide range of textural data, both from the Inyo and Valles drill cores and from the surfaces of other active and Recent flows. Based on examinations of dozens of these flows over the past 15 years, we find that this model does not account for many such textural observations. Furthermore, it cannot fully explain recent isotopic evidence from Mount St. Helens and the Mono Craters. In the present paper we summarize our textural and isotopic observations, discuss theoretical considerations, and suggest a more comprehensive model for effusive silicic volcanism that combines magma inflation and partial gas loss in the conduit with volatile migration and vesiculation during surface flow.

\section{Models of Volatile Distribution in Silicic Lava Flows}

In the first thorough study of water in rhyolite lavas, Friedman and Smith [1958] measured hydrogen isotopes in obsidian-perlite pairs from several Holocene lava flows. They found that hydrogen isotopic signatures for perlites typically matched those of local meteoric waters, while obsidians were significantly different. They concluded that the water in obsidian was magmatic. Eichelberger and Westrich [1981] measured water contents from silicic eruptive sequences in the western United States and found values of 0.5-1.0 wt $\%$ for rhyolitic obsidian clasts in explosive tephra deposits and 0.1-0.2 wt \% for obsidian from overlying flows. They proposed that the magma bodies which fed these eruptions were stratified with respect to volatiles, with upper zones of hydrous magma that produced the explosive ejecta and lower zones of drier magma that produced lava flows.

Taylor et al. [1983] reexamined eruptive sequences similar to those of Eichelberger and Westrich [1981], now using hydrogen and oxygen isotopic data. They found that rhyolitic samples with low water contents also had low $\delta \mathrm{D}$ values, and they proposed an alternative explanation for why obsidian in tephra should be waterrich while obsidian in associated lava flows was dry. According to this interpretation, the glassy ejecta retains the pre-eruption water content whereas the flow obsidian is produced by degassing of wet magma through the free escape of volatiles during ascent (the conduit was considered to be a chemically "open" system). They argued that the compositional homogeneity between the ejecta and flow obsidians indicated that both started in the chamber with similar water contents, and that the rising magma must have expanded to a highly inflated foam in order for the diffusional path lengths to be short enough to allow thorough degassing of the melt during the relatively short duration of the eruption.

Eichelberger et al. [1986] elaborated upon many aspects of this permeable foam concept. First, they argued that the presence of hormblende phenocrysts in Obsidian Dome lava demonstrated that the water content of the pre-eruption magma was at least $3.0 \mathrm{wt} \%$. Next they compared textures in distal and proximal drill cores through Obsidian Dome and claimed that the near-vent core lacked dense obsidian while the distal core had an obsidian layer underlying a $10-\mathrm{m}$-thick vesicular carapace. These relations were interpreted as indicating that distal obsidian formed by the collapse of bubbles in purnice like that found at the flow surface and in the vent area. They also calculated theoretical flow rates for gases out of the rising magma, through the funnel of loose debris around the conduit, and into the fractured country rock beyond the vent. These calculations implied that conduit permeabilities measured in the drill cores were high enough to allow the escape of sufficient water to account for observed differences between tephra and lava flow obsidians, while at the same time preventing fragmentation from occurring, if the "foam" had a vesicularity of 55-75 vol \%. Finally, they noted that the observed $0.1 \mathrm{wt} \%$ water content at the base of the 55 -m-thick flow indicated equilibrium with 1-atm conditions, in contrast to the $0.5 \mathrm{wt} \%$ expected for the 10 -bar pressures at these depths.

In summary, the volatile stratification model explains the common sequence of early explosive eruptions followed by effusion of lavas, and it relates differences in lava vesicularity to the combined influence of both water content and cooling rate variations. The permeable foam model is more specific, requiring that extruding silicic lavas (1) be composed entirely of highly inflated pumice at the time of emergence, (2) collapse due to their own weight from a porosity of as much as $75 \%$ to less than $5 \%$, and (3) lose most of their volatiles through the fractured conduit rock over a very short time span. As we will show in the next sections, none of these basic assumptions of the permeable foam model are supported by available field observations.

\section{Textural Observations of Holocene Silicic Lava Flows and Domes}

Glassy rhyolite and dacite flows and domes less than 2000 years old are particularly well exposed at several sites in the western United States, including Medicine Lake (California), South Sister (Oregon), and Newberry (Oregon) volcanoes, and Long Valley (California) Caldera. At each of these locations several extrusions are aligned, indicating that they were fed by dikes [Fink and Pollard, 1983]. The existence of one of these dikes was predicted on the basis of field evidence [Miller, 1985; Fink, 1985] and then confirmed by research drilling [Eichelberger et al., 1985] which also provided excellent interior views of one of the flows. Additional insights into texture development were obtained at Mount St. Helens (Washington) during the growth of its dacite dome from 1980 to 1986. We have mapped the distribution of glassy and vesicular textures on silicic flows at all of these volcanoes [Fink, 1983; Fink and Manley, 1987; Manley and Fink, 1987a; Anderson and Fink, 1989, 1990, 1992; Ondrusek et al., 1989]. In the following paragraphs we present observations and interpretations of these field relationships. 


\section{Textural Stratigraphy}

Most glassy rhyolite and dacite flows exhibit a range of vesicular textures on their upper surfaces, on their flow fronts, and in their interiors (Figure 1). The upper surface is made up primarily of a fractured finely vesicular carapace that grades downward into a dense glassy zone at a depth of 5-10 m. Drill cores and flow fronts reveal that this glassy zone is underlain by an irregular coarsely vesicular pumice (CVP) layer which in turn grades downward into a second glassy zone. The center of the flow is usually crystalline and overlies a third, lowermost glassy zone. The second dense glassy layer is flow-banded on a scale of millimeters, with alternating glassy and spherulitic laminae. Some spherulitic layers have vesicularities of over $50 \%$, whereas glassy layers are nonvesicular. The tops and bottoms of the flows are encased in breccia, consisting of glassy and vesicular blocks of different sizes. In some cases flows with higher phenocryst concentrations, like the Mount St. Helens dome, also have a 3-to 5-m-thick vesicular carapace that grades downward into a dense interior. Coarsely vesicular zones have not been positively identified in these more crystal-rich flows (Figure 1), although unusually dark outcrops seen on the Mount St. Helens dome surface in 1983 [Swanson et al., 1987] may have been coarsely vesicular lava that rose buoyantly from the flow interior. Experiments in which obsidian samples were heated under pressure, depressurized to expand into a foam, and then recompressed in order to resorb the vesicles have been cited as evidence that expanded silicic lava foam can collapse to dense obsidian without any trace of vesicles [Westrich and Eichelberger, 1989]. In these experiments, bubble resorption took place under load pressures of $0.4 \mathrm{MPa}$, corresponding to $20 \mathrm{~m}$ depth in a rhyolite lava flow. These experiments were conducted to demonstrate that Obsidian Dome, the interior of which is now largely dense glass, could have been extruded as a permeable foam which collapsed during surface flow. The experiments imply that every portion of Obsidian Dome below about $20 \mathrm{~m}$ would be dense and bubble-free. This is in conflict with the data of Eichelberger et al. [1986] in which Obsidian Dome is seen to have nonnegligible porosity at depths greater than $20 \mathrm{~m}$, as well as dense obsidian at depths less than $20 \mathrm{~m}$ (Figure 2).

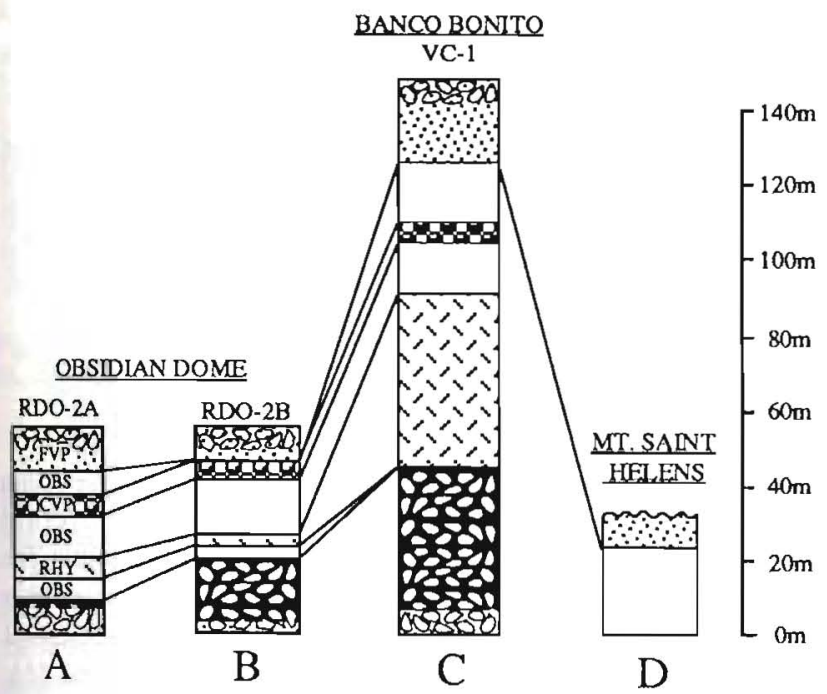

Fig. 1.Cross sections of Obsidian Dome (glassy rhyolite), Banco Bonito Flow (glassy myolite), and Mount St. Helens dome (crystal-rich dacite) showing arrangement of textural layers. Rhyolite cross sections based on drill cores; Mount St. Helens's cross section is based on exposures in cracks and flow fronts. RDO-2A drill hole is near flow front; RDO-2B is near vent. FVP is finely vesicular pumice; CVP, coarsely vesicul ar pumice; OBS, obsidian; and RHY, crystalline rhyolite. Texture pattems are the same for all four columns.

\section{Coarsely Vesicular Pumice}

Much attention has been focused on the zones of coarsely vesicular texture (Figure 2) and higher water content found in glassy rhyolite and dacite flows because of their possible association with explosive hazards [Fink and Manley, 1989]. This coarsely vesicular pumice (CVP) layer rises through the upper layers of dense obsidian as buoyant diapirs that penetrate the flow surface [Fink, 1980, 1983; Baum et al., 1989]. Eichelberger and Westrich [1984] showed that in the Inyo drill cores the glassier parts of this zone had water contents up to $0.5 \mathrm{wt} \%$, compared to values of 0.1 to $0.2 \mathrm{wt} \%$ throughout the rest of the flow stratigraphy. Westrich et al. [1988] presented more complete chemical data from the Inyo drill cores which showed that the CVP zone also had greatly enhanced concentrations of sulfur, chlorine, and fluorine. They attributed these increased values to the influence of meteoric water that entered the flow through its brecciated upper surface. Such anomalously high volatile contents were attributed by Fink and Manley [1987] to a redistribution of water vapor within the advancing flow while it was still active, with some of these gases perhaps being released during crystallization of the flow center. It was later proposed [Fink and Manley, 1989] that high volatile contents in the coarsely vesicular pumice zones could lead to endogenic explosions and dangerous pyroclastic flows similar to those observed at the Santiaguito dacite dome complex in Guatemala [Rose et al., 1977] and at Merapi Volcano in Indonesia [Zen, 1985].

Many of the flow surfaces that best expose coarsely vesicular pumice diapirs also display circular craters $20-30 \mathrm{~m}$ in diameter surrounded by locally derived blocks of prismatically jointed obsidian, suggesting explosions generated beneath or within the flows (Figure 3). These craters commonly extend down through surface layers of finely vesicular pumice and obsidian to CVP zones at depths of $10-15 \mathrm{~m}$, whereas the base of the flow is typically at depths of 30-60 m or more. Furthermore, some craters are found on the uppermost of several overlapping flow lobes and/or very near the vent; this indicates that these craters formed by an endogenic process rather than by interaction of the base of the flow with surficial water or snow. The circular shapes of most of these craters also imply that they formed after movement of the lava flow had ceased.

Flow fronts also provide extensive exposures of the relationship between the upper obsidian and coarsely vesicular layers. In practically all cases we have observed, these coarsely vesicular zones are overlain by dense obsidian layers which extend to within 3-5 $\mathrm{m}$ of the flow surface. Inspection of two dozen flows in Long Valley and on Medicine Lake Volcano further suggests that porosity in the CVP is best developed in those locations where the obsidian is most dense and glassy (least fractured and vesicular). The depth of the transition from dense obsidian to inflated coarsely vesicular pumice ranges from 5 to $15 \mathrm{~m}$ where it can be seen in flow fronts.

\section{Textures in Very Small Domes}

Some dike-fed chains of domes include extremely small extrusions. Two such groups on Medicine Lake Volcano contain discrete domes less than $5 \mathrm{~m}$ high and $30 \mathrm{~m}$ across (Figure $4 a$ ). In both cases, the small domes contain extensive outcrops of glassy obsidian (Figure 4b). One of the glass-rich domes along the Devil's Hill chain at South Sister Volcano [Scott, 1987; Fink and Manley, 1987] is also very small, with a height of $5 \mathrm{~m}$ and diameter of less than $40 \mathrm{~m}$. Clearly, the obsidian in these tiny domes could not have formed by foam collapse during surface flow. 
A
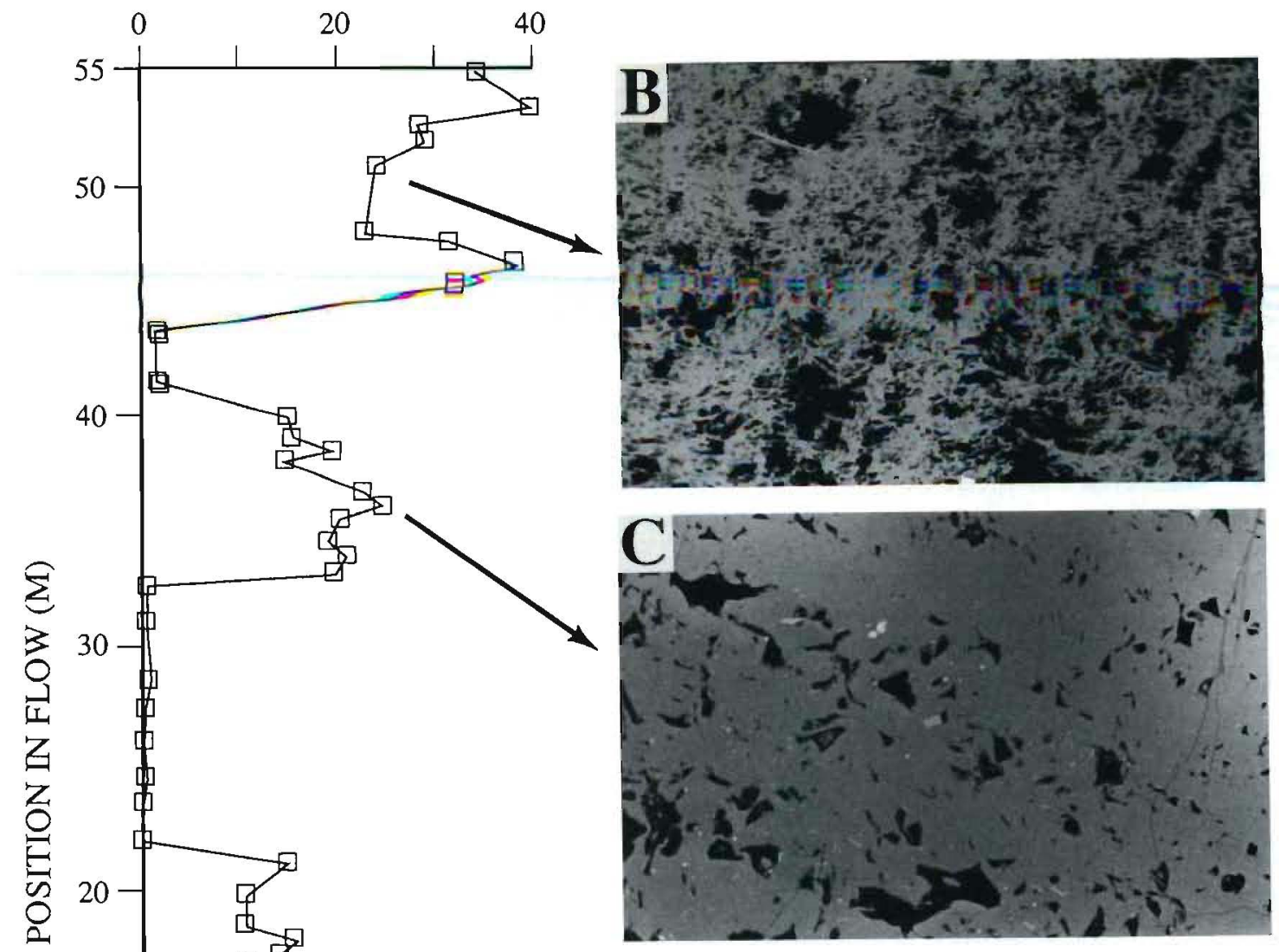

\section{Evidence for Vesiculation During Surface Flow}

Whereas the permeable foam model holds that, upon reaching the surface of the Earth, lava can only deflate, our observations of the surfaces of young Holocene rhyolite lava flows show that dense lava was able to inflate by vesiculation after reaching the surface. As stated above, much of the surface of a fresh rhyolite flow is made up of finely vesicular pumice, which has been broken into irregular blocks by stressing of the carapace during flow emplacement. In places, however, the obsidian layer normally beneath the pumice has been pushed up to the surface, often due to the rise of coarsely pumiceous diapirs from the flow interior. Where obsidian was pushed up in this manner, it was susceptible to rapid decompression as the mass breached the flow surface and fractured into spires and vertical faces, up to $4 \mathrm{~m}$ high, of hot, flow-foliated obsidian. The vertical fracture planes, originally quite smooth, now show a bulbous and ropy texture similar in appearance to the horizontal surface of a basaltic ropy pahoehoe flow (Figures $5 a$ and $5 b$ ). These bulbous features are caused by differential expansion of vesicles in individual flow foliations that differed in microlite content. Such relationships show that upon reaching the surface, the Obsidian Dome lava contained a dissolved water content in excess of the equilibrium value at atmospheric pressure, allowing it to vesiculate in response to decompression. This further implies 


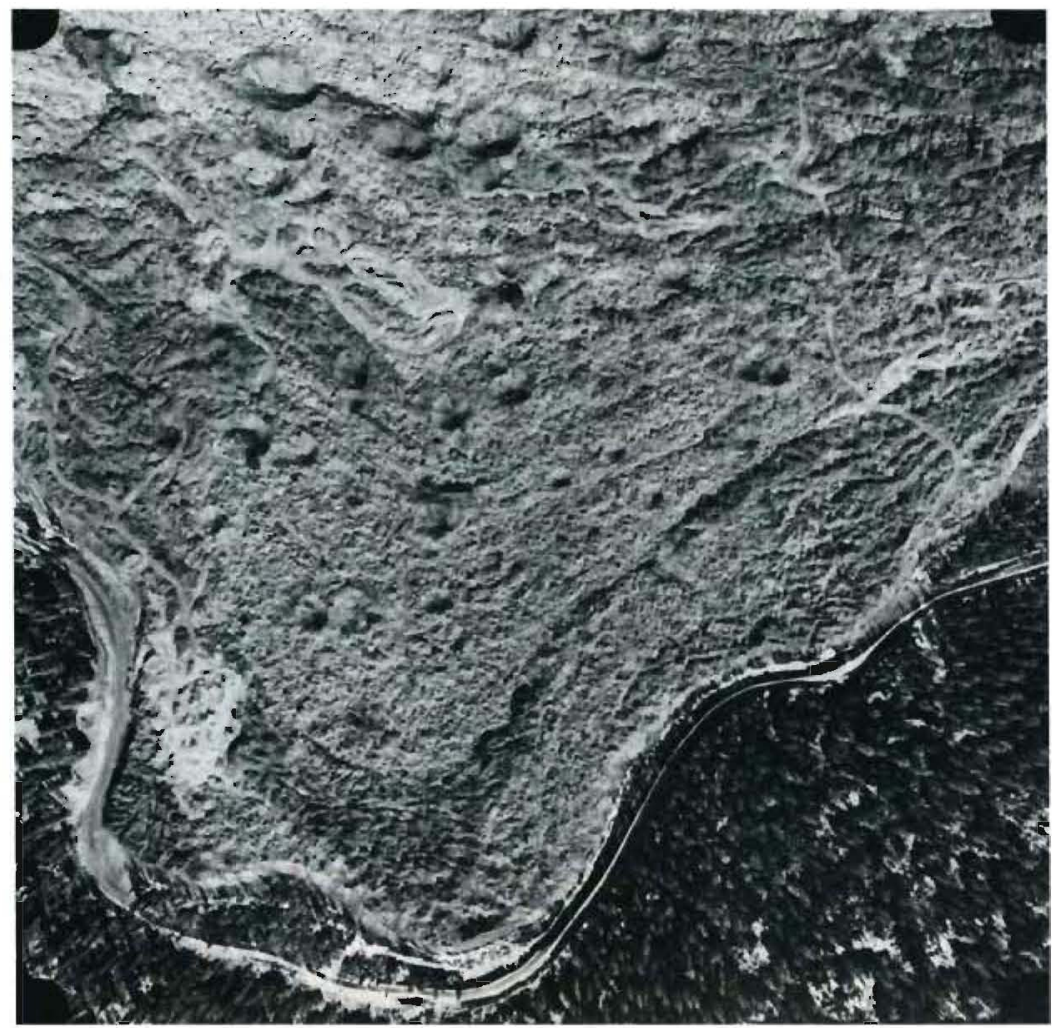

Fig. 3. Air photograph of south side of Glass Mountain thyolite flow, Medicine Lake Highland Volcano, Califomia, showing explosion pits that probably formed by explosive decompression. Pits have diameters of $15-25 \mathrm{~m}$ and extend down to a depth in the flow $(10-15 \mathrm{~m})$ where coarsely vesicular pumice zone occurs. Field of view is approximately $900 \mathrm{~m}$ across. North is to the top.

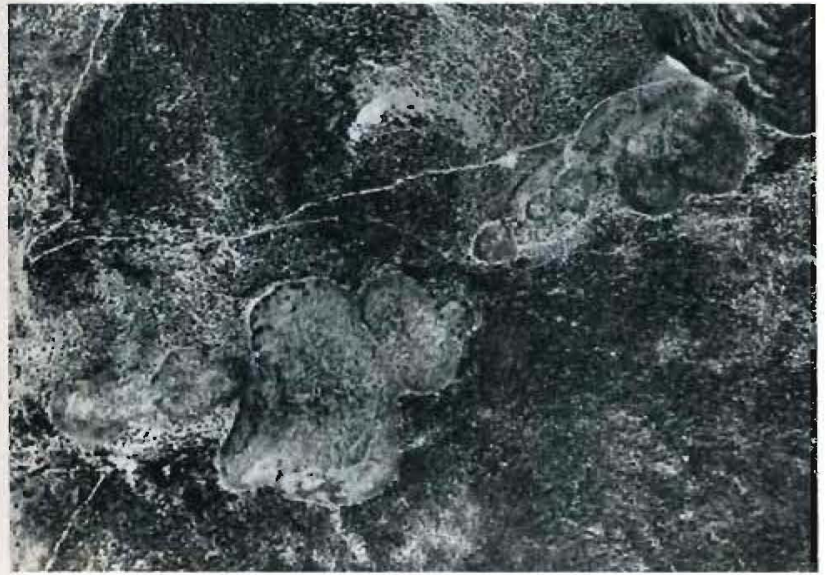

Fig. $4 a$. Aerial photo of chain of small rhyolite domes norhwest of Glass Mountain. Field of view is approximately $1800 \mathrm{~m}$ across. North is to the left.

that the surficial layer of finely vesicular pumice also formed by vesiculation on the surface.

Other features on rhyolite flows corroborate the evidence that upon decompression to atmospheric pressure at the ground surface, the lava is still able to vesiculate. In the coarsely vesicular pumice diapir adjacent to the RDO-2A drill site [Eichelberger et al., 1985] on Obsidian Dome, several narrow vertical fractures in the diapir are surrounded by small deposits of glassy tephra [Manley and Fink, 1987b]. Many of the tephra clasts show a smooth, curved, flow-foliated exterior and look like pieces of dense obsidian. Inside, however, they consist of highly inflated pumice. The smooth exteriors indicate that these clasts were dense and not

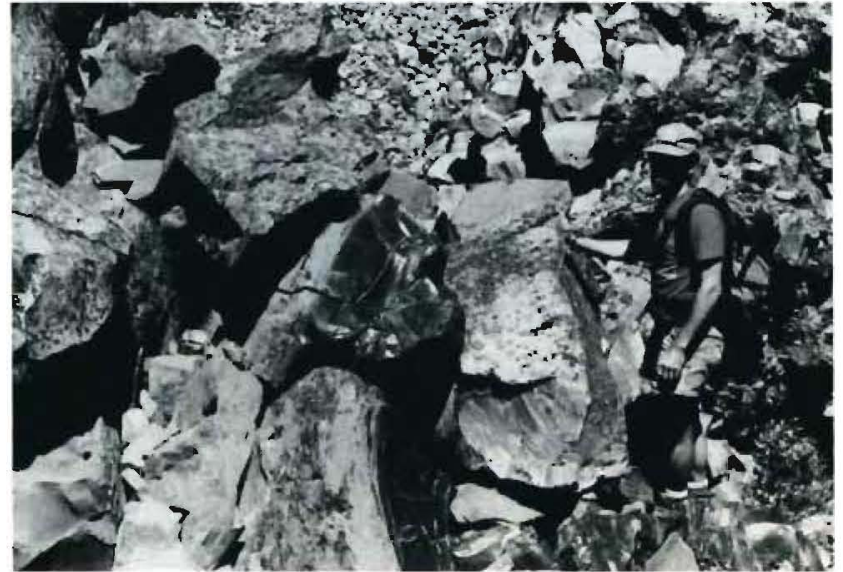

Fig. 4b. Closer view of small dome located near center of Figure $4 a$ showing glassy obsidian outcrop near its center. Dome is about $15 \mathrm{~m}$ in diameter and less than $3 \mathrm{~m}$ high. Note person for scale.

pumiceous when they were spalled from the parent lava. While the outer surface of the clast cooled sufficiently to inhibit vesicle growth, the inside remained warm longer, vesiculated, and expanded into pumice. Similar vesicular clasts that spalled from surface outcrops of dense obsidian are common on Panum Dome and the other aphyric flows of the Mono Craters chain, north of the Inyo volcanic chain (Figure $5 c$ ). These Mono lavas also show obsidian blocks with true bread crust textures, where internal vesiculation caused fracturing of the quenched skin of the block (Figure 5d).

The features described above are subtle and perhaps easily overlooked, but they show unequivocally that "degassed" rhyolite 


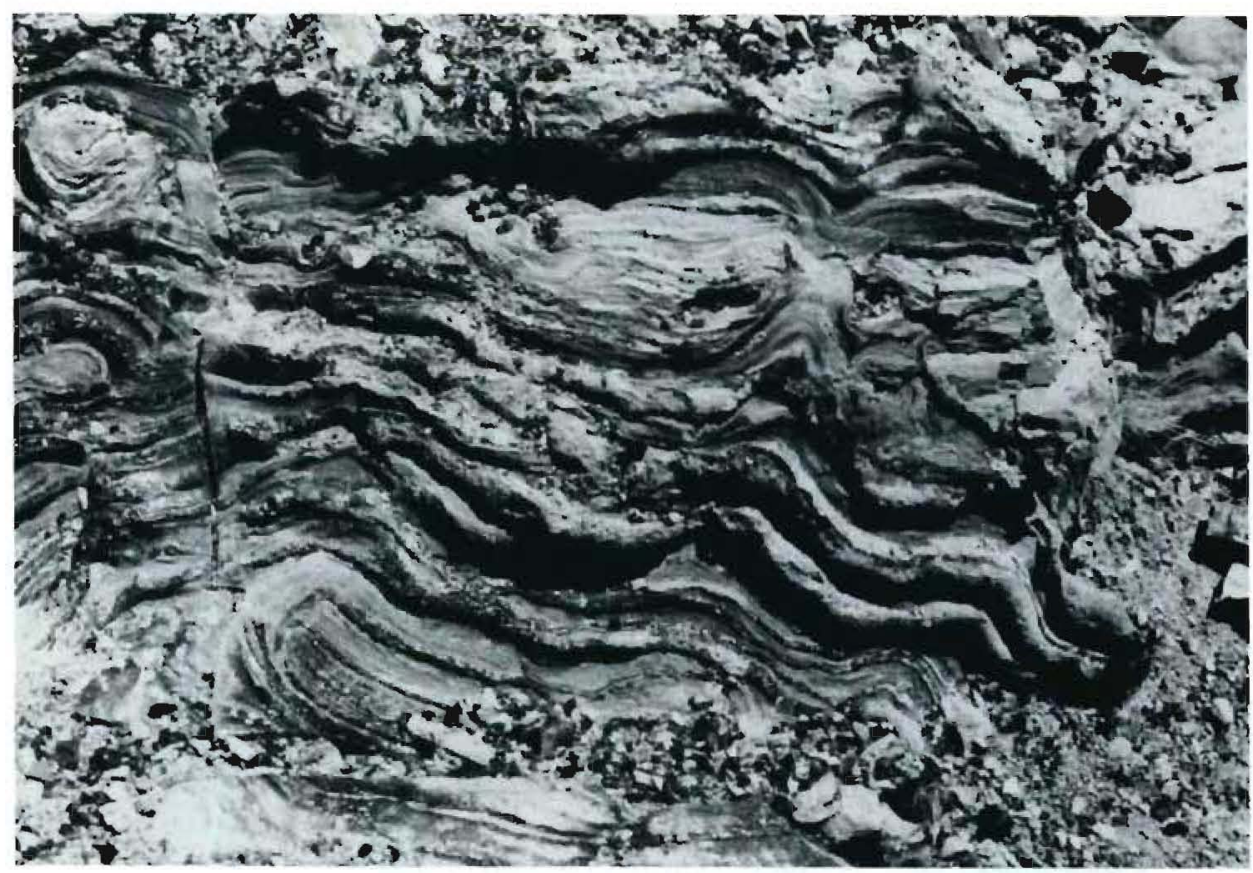

Fig. 5a. Flow-banded block of glassy thyolite that has vesiculated differentially at the flow surface. Inflated waterenriched layers now protrude from the originally flat vertical face of the block, which is about $1 \mathrm{~m}$ high with bands $1-2 \mathrm{~cm}$ thick. Sample from Panum Dome, Mono Craters.

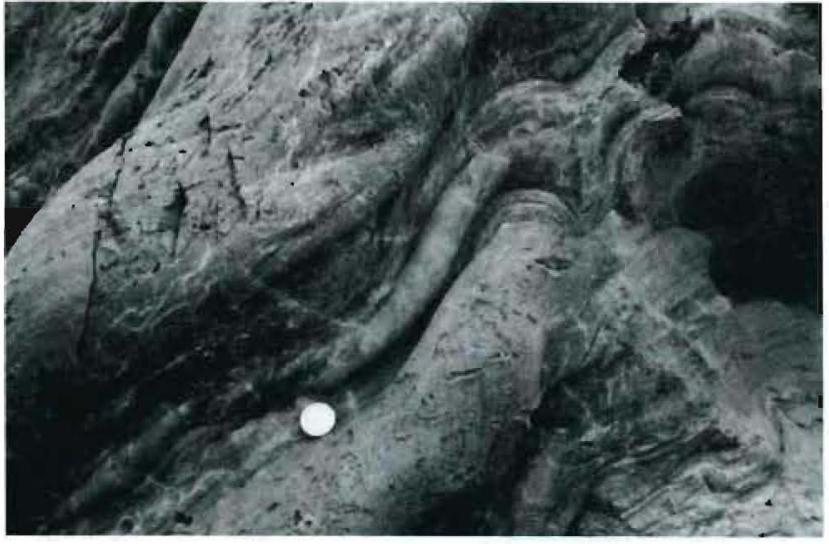

Fig. $5 b$. Similar differentially inflated verical face of a spine from Obsidian Dome. Protruding pahoehoelike structures reflect vesiculation of individual flow bands after sudden decompression at surface while face was still hot. The 2.4-cm-diameter coin is shown for scale.

lava is in fact still able to vesiculate while flowing across the Earth's surface during lava flow emplacement.

\section{Summary of Textural Observations}

Most of these spatial relationships are inconsistent with the idea that obsidian in silicic lavas forms by collapse during surface flow of an initially permeable foam. Westrich and Eichelberger's [1989] welding experiments showed that pressures equivalent to depths of $20 \mathrm{~m}$ are needed to cause bubbles to resorb so that pumice can revert to glass. Yet at numerous field localities, dense obsidian is observed at depths of $0-3 \mathrm{~m}$. Although some outcrops of this obsidian are pushed to the surface from the interiors of active flows, such an explanation cannot be invoked for the very small domes at Medicine Lake and South Sister volcanoes. Clearly, some of the lava reached the surface in a nonvesicular state rather than as pumice. Furthermore, the presence of distal, volatile-rich zones

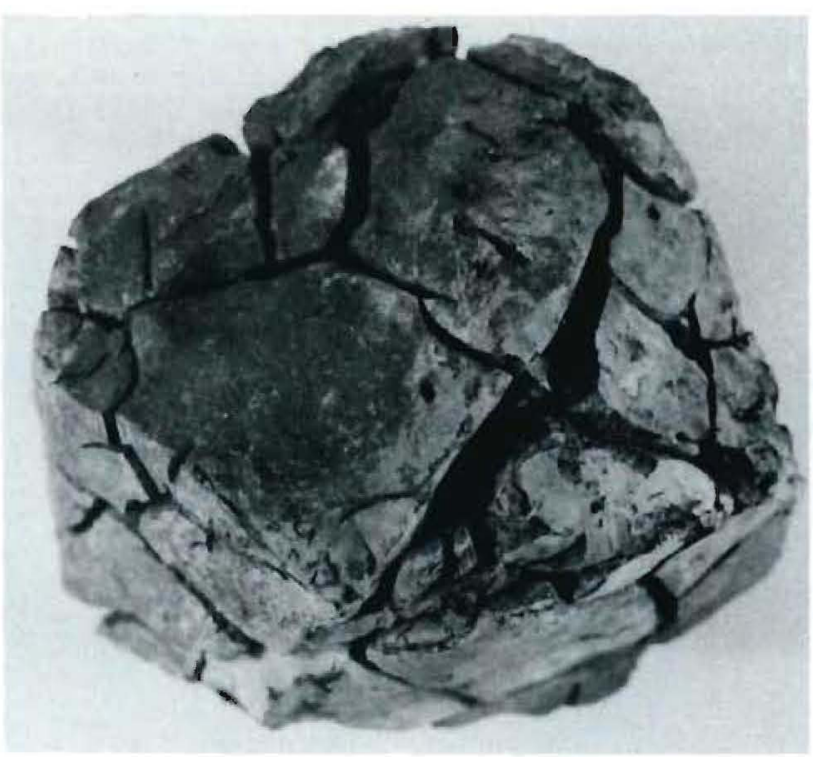

Fig. $5 c$. Inflated glassy clast ( $2 \mathrm{~cm}$ diameter) found near surface of Panum Dome. Note smooth, flow-banded surface and vesicular interior, indicating bubbles formed at the flow surface.

within silicic flows, implied by coarsely vesicular pumice diapirs and explosion craters, is inconsistent with a model of progressive foam collapse during flow advance.

\section{Observations of Active Silicic Extrusions}

\section{Vesiculation in the Mount St. Helens Lava Dome}

The extrusion of the Mount St. Helens dome in Washington provided opportunities to compare vesiculation models with temporal data. The Mount St. Helens dome was emplaced through a 


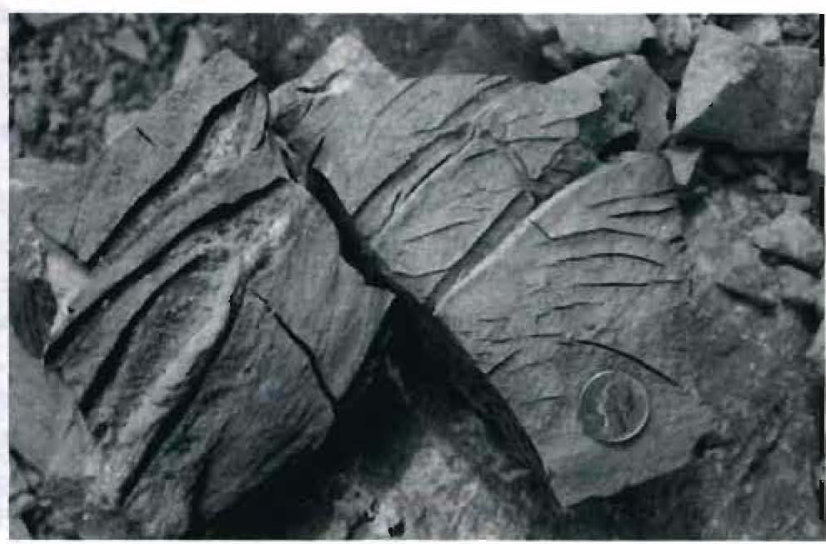

Fig. 5d. Bread-crusted block from flow front of Panum Dome. Texture forms by late-stage vesiculation of 1 he inlerior after the surface has chilled. The 2.4 cm-diameter coin is shown for scale.

series of more than 15 episodes between October 1980 and October 1986 [Swanson and Holcomb, 1990]. Each episode of extrusion followed a repose period of a few weeks to a year. Members of the U.S. Geological Survey's Cascades Volcano Observatory and other scientists were able to watch many phases of the eruption, and samples were collected from many of the lobes. These samples and observations allow us to document how vesiculation develops in an active silicic extrusion.

The surface of the Mount St. Helens dome is composed of lava with two contrasting textures: dense lava with vesicularity of less than $15-30$ vol $\%$, and scoriaceous lava with vesicularity of more than 50 vol \% (Figure 6). Where scoriaceous lava is present, it forms a 1- to 3-m-thick surface carapace. Time lapse photography and field observations showed repeatedly that the scoriaceous carapace formed by vesiculation of dense lava over a period of 1 3 days after extrusion [Swanson el al., 1987]. In no cases did scoriaceous lava emerge and then collapse to form the dense texture.
Hydrogen isotopic analyses of samples taken from many lobes of the Mount St. Helens dome permitted Anderson and Fink [1989] to distinguish three different mechanisms of degassing that operated during extrusion. Between eruptive episodes, degassing of magma in the chamber occurs through the diffusion of volatiles into nearby vesicles. Because this vapor remains in contact with the melt (a closed-system degassing process), the vesicularity increases until buoyancy becomes sufficient to overcome lithostatic forces and propel the magma toward the surface [Newman et al., 1988; Anderson and Fink, 1989]. During ascent through the conduit, volatiles released from the magma are able to escape (an open-system degassing process). Finally, as the magma approaches the surface and erupts as a lava flow, kinetically controlled gas loss takes place [Dobson et al., 1989]. The only significant degassing which occurs after lava emerges from the vent is associated with the formation of the scoriaceous carapace, where up to $0.3 \mathrm{wt} \%$ water may be released during surface vesiculation (Figure 7) of originally dense lava [Anderson and Fink, 1990]. This model is also consistent with recent isotopic measurements of rhyolite lavas from the Mono Craters [Newmanet al., 1988; Dobson et al., 1989]. All three of the identified gas loss mechanisms (closed, open, and kinetic) can occur without the presence of a permeable foam.

\section{Degassing Between Eruptive Episodes}

Another key assumption of the permeable foam model is that the beginning of lava effusion is contemporaneous with the cessation of explosive activity, so that the reduction of volatile content from around 3.0 or 4.0 to less than $0.2 \mathrm{wt}_{\mathrm{o}} \mathrm{H}_{2} \mathrm{O}$ must be very rapid. This is one of the main features the permeable foam model was formulated to explain. However, there are as yet no constraints on the duration of the transition from explosive to effusive activity during rhyolitic eruptions. For instance, the only subaerial rhyolitic dome-building eruption in recent times, extrusion of the Novarupta dome (Alaska) after the June 1912 Valley of Ten Thousand Smokes Plinian and ash flow eruptions [Hildreth, 1983,

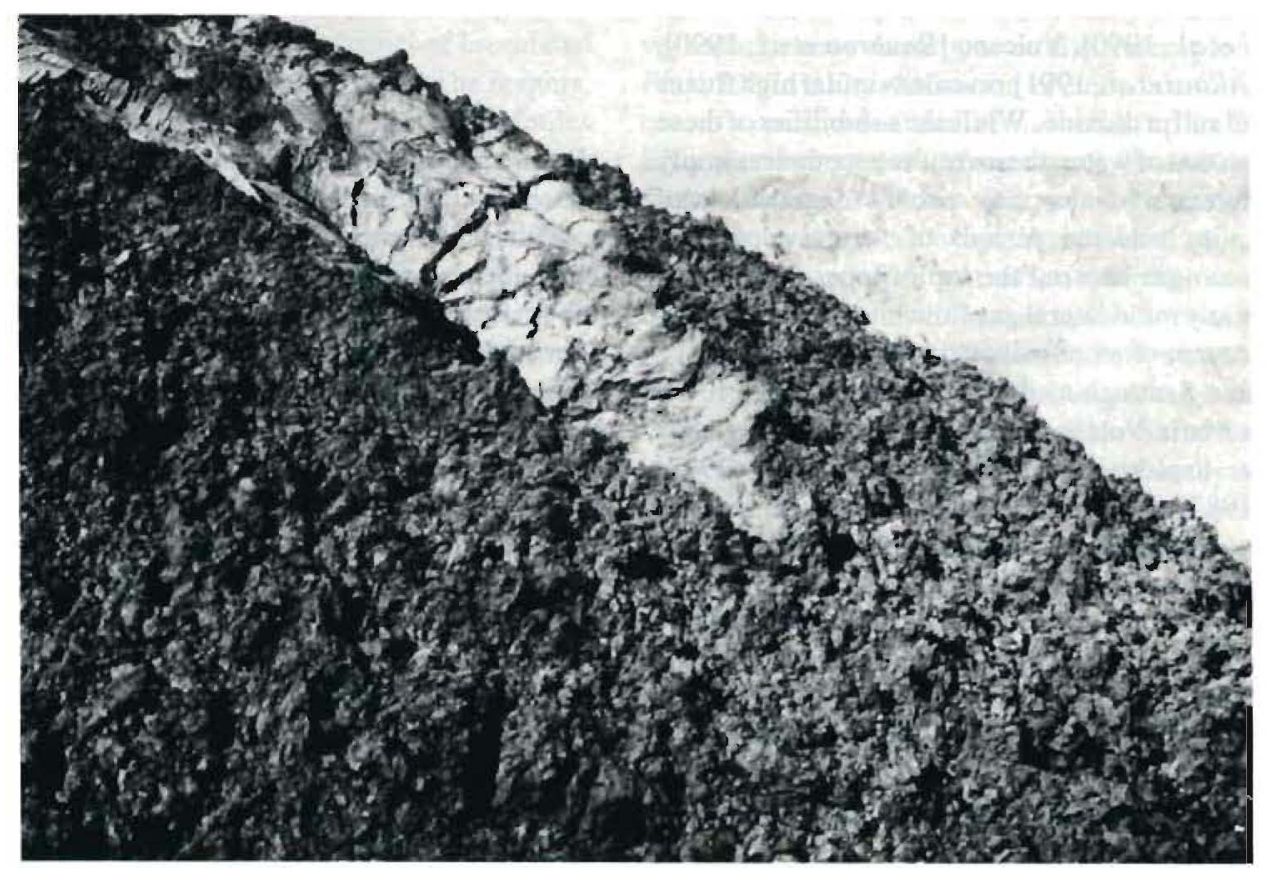

Fig. 6. Oblique air photograph of Mount St. Helens dome (June 1981 lobe) showing areas of smooth and scoriaceous texture adjacent to a crease structure [Anderson and Fink, 1992]. Crease structure is approximately $30 \mathrm{~m}$ across at its widest point. 

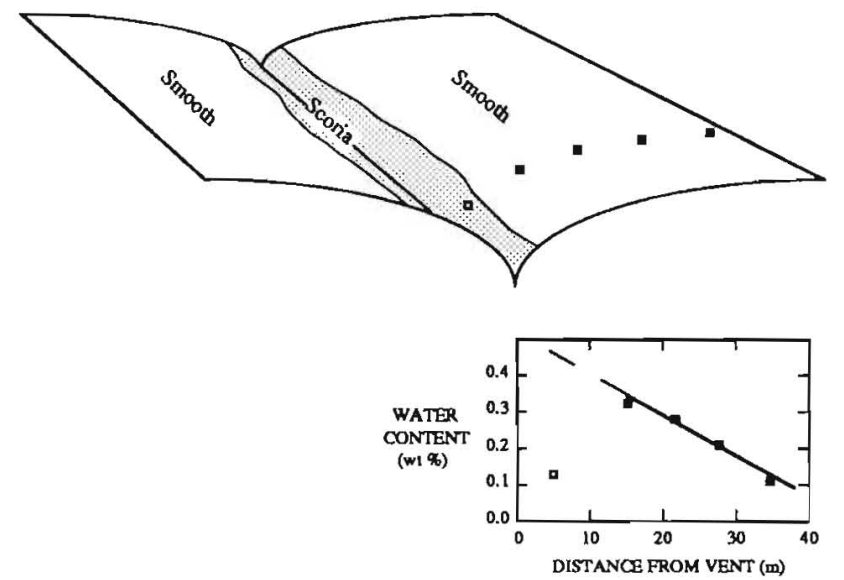

Fig.7. (a) Sketch map of smooth crease structure over vent of May 1986 lobe of Mount St. Helens dome showing central strip of scoriaceous lava and positions of five samples analyzed for water content, and $(b)$ water contents of samples whose positions are shown in Figure $7 a$. Note that water contents steadily increase toward the axis of the crease structure for samples of smooth lava, but decrease abruptly for scoriaceous sample, reflecting gas loss associated with vesiculation at surface.

1987], was not observed, and the area was not visited until 1917 [Griggs, 1922]. While the dome might have formed immediately after cessation of explosive activity, it could have formed at nearly any time in the first 4 or 5 years following the 1912 eruption.

Assumptions that loss of 3.0 or $4.0 \mathrm{wt} \% \mathrm{H}_{2} \mathrm{O}$ must be very rapid also ignore the potential role of volatile loss from a magma body before an eruption. Measurements of gas content in the plume over the Mount St. Helens dome showed that large amounts of water vapor, sulfur dioxide, carbon dioxide, and other volatiles were lost between extrusive events throughout the dome's 6-year period of growth [Casadevall et al., 1981, 1983]. For example, more than $6.6 \times 10^{6} \mathrm{~kg} / \mathrm{d}$ of $\mathrm{SO}_{2}$ were detected during the intervals separating the early explosive eruptions in 1980 , and more than $4.4 \times 10^{5} \mathrm{~kg} / \mathrm{d}$ were measured between subsequent dome-building events in 1980 1982. Measurements from summit areas and flanks of volcanoes such as White Island, New Zealand [Rose et al., 1986], Redoubt, Alaska [Casadevall et al., 1990], Vulcano [Baubron et al., 1990], and Mt. Etna, Italy [Allardet al., 1991] revealed similar high fluxes of carbon dioxide and sulfur dioxide. While the solubilities of these species are lower than that of water, these results nonetheless imply that significant volumes of water may also be degassed from shallow magma bodies between periods of eruptive activity [Gerlach, 1991]. Such gas loss out the top of a passive magma column may obviate any rapid lateral gas flow into the walls of the conduit during the course of an effusive eruptive episode.

The currently active Santiaguito dacite dome complex on the south flank of Santa Maria Volcano began growing 20 years after a highly destructive explosive eruption in 1902 [Rose, 1973; Williams and Self, 1983]. The dense lava that began to emerge in 1922 thus had had two decades to lose its volatiles prior to rising through the conduit. During subsequent emplacement, predominantly explosive episodes have occurred at 7 - to 20 -year intervals, alternating with periods of more quiet effusion. The explosive phases have nearly all been characterized by the presence of a prominent plume which can account for a considerable fraction of the degassing necessary to give the low $(0.1 \mathrm{wt} \%)$ water contents of the Santiaguito lavas [Rose, 1987; Anderson et al., 1990].

Further evidence for degassing in a shallow environment comes from observations of the 1977-1978 dacitic eruption of Usu Volcano, in Hokkaido, Japan. Activity began in August 1977 with explosive eruptions of ash and pumice that lasted a week [Yokoyama et al., 1981]. After explosions ceased, a portion of the caldera floor was upheaved by emplacement of a cryptodome, and shallow seismicity continued, decreasing exponentially with time through late 1978 [Yokoyama et al., 1981; Watanabe,1984]. The earthquake focii outlined a vertical cylinder $1.5 \times 1 \mathrm{~km}$ in diameter and roughly $2 \mathrm{~km}$ deep, with an earthquake-free zone in the center of the cylinder beneath the area of greatest surface doming. Watanabe [1984] interpreted this activity as indicating that magma in a shallow cylindrical chamber, perhaps cut off from deeper levels, was inflating by gradual vesicle growth long after the explosive phase of the eruption had ceased. This expansion of the magma was responsible for emplacement of the cryptodome, and for earthquake activity around the exterior of the chamber. If this interpretation is correct, the magma, even at depths of up to $2 \mathrm{~km}$, was able to slowly vesiculate over an extended time period. Such vesiculation at shallow depths, at times when no eruption is occurring, may serve to decrease the volatile content of magma that does, at some later time, eventually reach the surface. One can envision a case where cessation of explosive activity is followed first by passive gas loss in a "static" shallow conduit environment, and then by extrusion of the degassed magma as a lava dome or flow, akin to the process suggested by Wolff [1986].

Very fine-grained subvolcanic plutonic rocks have often been interpreted as having been quenched from a magma by loss of a volatile phase, which shifts the solidus of the magma to higher temperatures and solidifies the pluton more quickly than cooling alone [McDowell, 1978; Fridrich and Mahood, 1984; O'Brient, 1986]. Thus, even magma that was not drawn into the conduit and did not erupt was efficien tly degassed during an eruption, implying that explosive eruptions may bleed off more magmatic volatiles than is accounted for by the mass of ejected juvenile material.

Although the above observations are compatible with the idea that some degassing occurs through conduit walls, they show that significant gas loss may take place in deeper portions of the magmatic system and again at the surface during carapace formation. Therefore, rapid expansion to a foam is not required to explair. the loss of any volatiles during ascent of an extruding magma.

\section{Constraints from Eruption Dynamics}

In this section we consider how models of eruption dynamics can be used to constrain the methods of degassing and development of vesicularity in lavas. In an explosive silicic eruption, the depth at which the rising magma begins to nucleate vesicles (the "exsolution surface"; Figure 8) is controlled by the load pressure at which it becomes saturated with dissolved water. As the vesicles grow by decompression and by diffusion of water from the melt, the void fraction of the magma increases. It is commonly assumed that at void fractions of around 70 to $80 \%$, the magma loses much of its ductility and will fragment into ash and pumice clasts [e.g., Sparks, 1978]. The depth at which this "fragmentation surface" occurs will be at some height above the exsolution surface. Above the fragmentation surface, the ash and pumice clasts are accelerated out of the vent. If the rising magma actually expands into a highly permeable foam, this foam interval will be located between the exsolution and fragmentation surfaces.

The portion of the conduit above the fragmentation surface can be widened or eroded into a funnel by the violent action of the expanding mixture of gas, ash, and pumice. Lithic blocks caught up in explosive eruptions and deposited in air fall or ignimbrite units are most likely to come from depths in the conduit above the 
a

b

1 1)
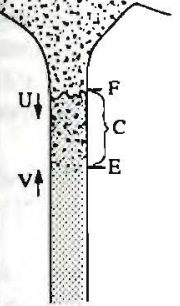

c

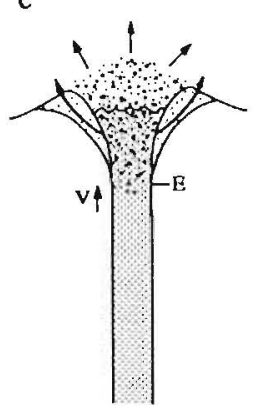

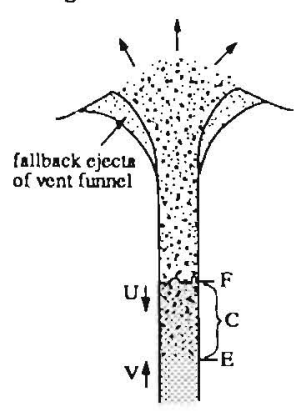

Fig. 8. Schematic diagrams of processes occurring during explosive eruptions of silicic magma. Letters indicate level of first exsolution of volatiles $(E)$, fragmentation surface $(F)$, critical interval of vesicular but nondisrupted magma (C), velocity of downward migration of fragmentation surface (u), and velocity of magma rise (v). Not to scale. Adapted from Sparks [1978]. (a) Situation near the beginning of an explosive eruption, with fragmentation level near the ground surface. Mechanical action of the expanding pumice, ash, and gas mixture has formed a crater above the fragmentation level. (b) During the course of an eruption, the fragmentation level and the critical interval will migrate to greater depths in the conduit as explosive removal of fragmented lava unloads the magma column. The magnitude of $u$ is thus greater than that of v. (c) As formulated by Eichelberger and coworkers, the permeable foam model implies that an explosive eruption evolves somehow from the situation in Figure $8 b$ to that in Figure $8 c$. Volatiles (heavy arrows) might then be lost rapidly through the porous vent funnel, leading to an effusive eruption. For this to occur, either (1) the velocity of the rising magma (v) must increase, or (2) the vesicularity or dissolved water content in the magma must decrease. Case 1 is counterintuitive and unrealistic. Case 2 is inconsistent with another basic assumption of the permeable foam model (that volatiles are not stratified).

fragmentation surface, since the laminar flow of coherent silicic magma has little ability to erode the conduit walls. Differing concentrations and lithologies of lithic blocks in a sequence of pyroclastic deposits from the same vent have been interpreted as representing fluctuations in the depth of the fragmentation surface during the course of the eruption [Wright and Walker, 1977; Self et al., 1980; Cas and Wright, 1987; W.P.Nash, personal communication, 1991].

The permeable foam model as formulated by Eichelberger and coworkers depends on the presence of a vent funnel of brecciated debris around the uppermost portion of the conduit. The magma, once it expands into a foam, is envisaged to lose its volatiles through this highly porous debris shortly before it is extruded onto the Earth's surface. For this to occur, the interval of foam in the conduit (the critical interval for passive loss of gas) must rise into the vent funnel (Figure $8 c$ ). However, since formation of the vent funnel required that the fragmentation surface (and thus the critical foam interval as well) was located at a greater depth than the funnel, bleeding-off of volatiles through the permeable walls requires that the critical foam interval rise into the funnel if the cruption is to proceed from explosive to nonexplosive activity. For the critical foam interval to migrate upward, assuming no change in $\mathrm{H}_{2} \mathrm{O}$ content in the magma chamber, either the mass eruption rate or driving pressure must increase. This leads to the improbable scenario that the transition from explosive to nonexplosive activity requires increasing the violence of the eruption, instead of the reverse. Also, increases in eruption rate or eruption velocity would decrease the amount of time available for gas loss to take place, making efficient degassing less likely.

If the position of the fragmentation surface truly does rise to shallower depths during an eruption, thus allowing the magma to degas almost completely in the shallowest portion of the conduit, this implies that gas is also being lost from the magma below the vent funnel (again, assuming no gradient in $\mathrm{H}_{2} \mathrm{O}$ in the magma chamber). We suggest that during any large or small silicic eruption, nontrivial amounts of gas are lost to the country rock at depth (see also Jaupart and Allegre [1991]). The efficiency of this process will naturally decrease with increasing conduit diameter and increasing eruption driving pressure. Thus the greatest (Plinian) eruptions, with the largest-diameter conduits and highest driving pressures, may be largely unaffected by this mechanism. Small eruptions, involving minor volumes of juvenile material and small conduits and driving pressures, would be very susceptible to such gas loss, and this could lead to profound changes in eruption style.

It would appear that only through significant degassing at depths greater than the vent funnel, or by significant gas loss some time before the start of an effusive eruption, can the transition from explosive to effusive activity by gas loss through a permeable foam be consistent with presently accepted models of vesiculationdriven explosive enuptions [Sparks, 1978; Wilson et al, 1980].

\section{Model for Effustve Silicic Volcanism}

The observations of vesicular textures and active extrusions that we have presented suggest that certain elements of both the volatile stratification and permeable foam models are valid. Some domeforming eruptions clearly tapped magma bodies strongly zoned in volatiles and other chemical components [e.g., Congdon and Nash, 1988]. Mineralogic and petrologic relationships, however, require that the magma which eventually forms many other glassy rhyolite domes and flows have high volatile contents similar to that which forms the initial explosive products. Some of the required gas loss may occur through the porous walls of the conduit during ascent if eruption rates are low enough, but additional volatiles escape before effusive episodes. The combined result of these two effects is that the magma that reaches the surface is nearly equilibrated to atmospheric pressure (0.1-0.4 wt \% volatiles) and generally has low vesicularity (10-30 vol \%), similar to that seen in the Mount $\mathrm{St}$. Helens dome lavas. This porosity is generally too low to allow significant additional gas loss to occur by bubble collapse.

Once lava emerges and moves away from the vent, additional vesiculation may occur by several different processes [Manley and Fink, 1987a]. Crystallization of anhydrous minerals in the flow center expels water that forms voids up to $1 \mathrm{~mm}$ in diameter. Effervescence at the surface due to the final release of pressure forms a finely vesicular carapace on glassy rhyolite flows and a scoriaceous carapace on crystal-rich dacite flows. Finally, exsolution and migration of volatiles through microcracks within the moving flow may result in volatile-rich zones beneath the flow's rigid, brittle carapace. These coarsely vesicular zones can only develop in flows that are thick or long enough to allow appreciable volatile exsolution and redistribution. Short flows, like those that make up the Mount St. Helens dome, generally do not form internal zones of enhanced volatile content. Where they do form, these water-enriched layers can rise to the flow surface as regularly spaced diapirs or decompress explosively if exposed by collapse of the flow front on steep slopes.

The distributions of textures observed on the surfaces and in the interiors of silicic lava extrusions do not preclude either method of gas loss or either model of magma chamber heterogeneity. Stratified magma bodies may erupt water-rich explosive products first, followed by drier domes and flows, and eruptions may tap homogeneous magma bodies at different rates, resulting in explosive followed by effusive eruptions. Both can result in lavas that have low water contents and that develop internal vesicular zones during 
surface advance if travel distances and flow thicknesses are great enough. However, observations of vesicular textures and of active flows are not consistent with the idea that flows emerge as permeable foams that compress to dense glassy lava during surface advance.

Degassing is not complete upon extrusion of silicic lava. The magma reaches the surface with a water content at least slightly greater than the value at which it would be in equilibrium with the atmosphere. Sudden decompression of hot material, especially when combined with mechanical disintegration, can give rise to an avalanche of hot, actively vesiculating, comminuting lava, forming a devastating pyroclastic flow. Smaller explosions and sudden ejection of hot blocks from apparently stable flow surfaces are other probable hazards on active flows, especially to scientists studying these extrusions. A better appreciation of the likelihood of this type of hazard might have prevented the tragic loss of life that occurred at Unzen Volcano, Japan, in June of 1991, where sudden collapse of much of the growing, oversteepened lava dome led to a pyroclastic flow that claimed the lives of 42 people, including three volcanologists.

Acknowledgments. This work was supported by NSF grants EAR 88-17458 and EAR 90-18216, DOE grant DE-FG 0385401339 (Inyo Scientific Drilling Program), and NASA grant NAGW 529 from the Planetary Geology and Geophysics Program. We thank Don Swanson, Claude Jaupan, Andrea Borgia, Steve Blake, Jaime Ondrusek, Jean-Christophe Komorowski, and Wendell Duffield for stimulating discussions, Bill Rose and Mike McCurry for helpful reviews, Dan Ball for photographic work, and Susan Selkirk for drafting.

\section{REFERENCES}

Allard, P., J. Carbonnelle, D. Dajlevic, J. Le Bronec, P. Morel, M.C. Robe, J.M. Maurenas, R. Faivre-Pierret, D. Martin, J.C. Sabroux, and P. Zettwoog, Eruptive and diffuse emissions of $\mathrm{CO}_{2}$ from Mount Etna, Nature, 351,387391, 1991.

Anderson, S.W., and J.H. Fink, Hydrogen isotope evidence for extrusion mechanisms of the Mount St. Helens lava dome, Nature, 341, 521-523, 1989.

Anderson, S.W., and J.H. Fink, The development and distribution of surface textures at the Mount St. Helens dome, International Association of Volcanology and Chemistry of the Earlh's Interior Proc. Volcanol.,2, 25-46, 1990.

Anderson, S.W., and J.H. Fink, Crease structures: Indicators of emplacement rates and surface stress regimes of lava flows, Geol. Soc. Am. Bull., 104, 615-625, 1992.

Anderson, S.W., J.H. Fink, and W. I. Rose, Jr., Volatile content and eruptive behavior of silicic lava domes: A comparison of Santiaguito (Guatemala) and Mount St. Helens (WA) (abstract), EOS Trans. AGU, 71, 1720, 1990.

Baubron, J.C., P. Allard, and J.P. Toutain, Diffuse volcanic emissions of carbon dioxide from Vulcano Island, Italy, Nature, 344, 51-53, 1990.

Baum, B., W. Krantz, J.H. Fink, and R. Dickerson, Taylor instabilities in thyolite flows, J. Geophys. Res., 94, 5815-5828, 1989.

Cas, R.A.F., and J.V. Wright, Volcanic Successions, 487 pp., Allen and Unwin, London, 1987.

Casadevall, T.J., D.A. Johnston, D.M. Harris, W.I. Rose, Jr., L.L. Malinconico, R.E. Stoiber, T.J. Bomhorst, S.N. Williams, L.Woodruff, and J.M. Thompson, $\mathrm{SO}_{2}$ emission rates at Mount St. Helens from March 29 through December, 1980, in The 1980 Eruptions of Mount St. Helens, Washington, U.S. Geol. Surv. Prof. Pap. 1250, 193-200, 1981.

Casadevall, T., W. Rose, T. Gerlach, L.P. Greenland, J. Ewen, R. Wunderman, and R. Symonds, Gas emis sions and the eruptions of Mount St. Helens through 1982, Science, 221, 1383-1385, 1983.

Casadevall, T.J., C.A. Neal, R.G. McGimsey, M.P. Doukas, and C.A. Gardner, Emission rates of sulfur dioxide and carbon dioxide from Redoubt Volcano, Alaska during the 1989-1990 eruptions (abstract), Eos Trans. $A G U, 71,1702,1990$.

Congdon, R.D., and W.P. Nash, High-fluorine rhyolite: An eruptive pegmatite magma at the Honeycomb Hills, Utah, Geology, 16, 1018-1021, 1988.

Dobson, P.F., S. Epstein, and E.M. Stolper, Hydrogen isotope fractionation between co-existing vapor and silicate glasses and melts at low pressures, Geochim. Cosmochim. Acla, 53, 2723-2730, 1989.
Eichelberger, J.C., Are extrusive thyolites produced from permeable foam eruptions? Reply, Bull. Volcanol., 51, 72-75, 1989.

Eichelberger, J.C., and H.R. Westrich, Magmatic volatiles in explosive thyolitic eruptions, Geophys. Res. Letl. 8, 757-760, 1981.

Eichelberger, J.C., and H.R. Westrich, Degassing of magma in an obsidian flow and inferred degassing behavior at depth, in Active Tectonic and magmatic processes beneath Long Valley Caldera, Eastem California, edited by D. Hill, A. Ryall, and R. A. Bailey, U.S. Geol. Surv. Open File Rep. 84-939, 147-150, 1984.

Eichelberger, J.C., P.C. Lysne, and L.W. Younker, Research drilling at Inyo domes, Long Valley Caldera, California, Eos Trans. AGU, 65, 721-724, 1984.

Eichelberger, J.C., P.C. Lysne, C.D. Miller, and L.W. Younker, Research drilling at Inyo domes, Califomia: 1984 results, Eos Trans. AGU, 66, 186187,1985 .

Eichelberger, J.C., C.R. Carrigan, H.R. Westrich, and R.H. Price, Nonexplosive silicic volcanism, Nature, 323, 598-602, 1986.

Fink, J.H., Gravity instability in the Holocene Big and Litte Glass Mountain thyolitic obsidian flows, northem Cal ifomia, Tectonophysics, 66, 147-166, 1980.

Fink, J.H., Structure and emplacement of a rhyolitic obsidian flow: Little Glass Mountain, Medicine Lake Highland, northem Califomia, Geol. Soc. Am. Bull., 94, 362-380, 1983.

Fink, J.H., and C.R. Manley, Origin of pumiceous and glassy textures in rhyolite flows and domes, in Emplacement of Silicic Domes and Lava Flows, edited by J. H. Fink, Spec. Pap. Geol. Soc. Am., 212, 77-88, 1987. Fink, J.H., Geometry of silicic dikes beneath the Inyo domes, Califomia, $J$. Geophys. Res. 90, 1127-1133, 1985.

Fink, J.H. and C.R. Manley, Explosive volcanic activity generated within advancing silicic lava flows, in Volcanic Hazards, edited by J. Latter, International Association of Volcanology and Chemistry of the Earth's Inserior Proc. Volcanol., 1, 169-179, 1989.

Fink, J.H., and D.D. Pollard, Structural evidence for dikes beneath silicic domes, Medicine Lake Highland Volcano, California, Geology, 11, 458$461,1983$.

Fridrich, C.J., and G.A. Mahood, Reverse zoning in the resurgent intrusions of the Grizzly Peak cauldron, Sawatch Range, Colorado, Geol. Soc. Am. Bull., 95, 779-787, 1984.

Friedman, I., Are extrusive rhyolites produced from permeable foam eruptions?, Bull. Volcanol., 51, 69-71, 1989.

Friedman, I., and R.L. Smith, The deuterium content of water in some volcanic glasses, Geochim. Cosmochim. Acla, 15, 218-228, 1958.

Gerlach, T.M., Present-day $\mathrm{CO}_{2}$ emissions from volcanos, Eos Trans. AGU, 72, 249-255, 1991.

Goff,F.,J. Rowley, J.N. Gardner, W. Hawkins, S. Goff, R. Charles, D. Wachs, L. Maassen, and G. Heiken, Initial results from VC-1, first Continental Scientific Drilling Program core holes in Valles Caldera, New Mexico, $J$. Geophys. Res., 91, 1742-1752, 1986.

Griggs, R.F., The Valley of Ten Thousand Smokes, 340 pp., National Geographic Society, Washington, D.C., 1922.

Heiken, G., Plinian-type eruptions in the Medicine Lake Highland, California, and the nature of the underlying magma, J. Volcanol. Geotherm. Res., $4,375-402,1978$.

Hildreth, W., The compositionally zoned eruption of 1912 in the Valley of Ten Thousand Smokes, Katmai National Park, Alaska, J.Volcanol. Geotherm. Res., 18, 1-56, 1983.

Hildreth, W., New perspectives on the eruption of 1912 in the Valley of Ten Thousand Smokes, Katmai National Park, Alaska, Bull. Volcanol., 49, 680693, 1987.

Jaupar, C., and C.J. Allegre, Gas content, eruption rate and instabilities of eruption regime in silicic volcanoes, Earth Planet. Sci. Let., 102, 413-429, 1991.

Manley, C.R., and J.H. Fink, Intemal textures of thyolite flows as revealed by research drilling, Geology, 15, 549-552, 1987a.

Manley, C.R., and J.H. Fink, Endogenic explosive activity on thyolite flows (abstract). Geol. Soc. Am. Abstr. Programs, 19, 758, 1987 b.

McDowell, S.D., Litte Chief granite porphyry: Feldspar crystallization history, Geol. Soc. Am. Bull., 89, 33-49, 1978.

Miller, C.D., Holocene eruptions at the Inyo volcanic chain, CalifomiaImplications for possible eruptions in the Long Valley Caldera, Geology, 13, 14-17, 1985.

Newman, S., S. Epstein, and E. Stolper, Water, carton dioxide, and hydrogen isotopes in glasses from the ca. 1340 A.D. enuption of the Mono Craters, Califomia: Constraints on degassing phenomena and initial volatile content, J. Volcanol. Geotherm. Res., 35, 75-96, 1988.

O'Brient, J.D., Preservation of primary magmatic features in subvolcanic 
pegmatites, aplites, and granite from Rabb Park, New Mexico, Am. Mineral., 71, 608-624, 1986.

Ondrusek, J.O., P.R. Christensen, and J.H. Fink, Composition and textural variations in Java from Glass Mountain, Califomia: Evidence from themal spectroscopy (abstract), in Continental Magmatism, lA VCEI General Assembly Abstracts, Bull. N. M. Bur. Mines Miner. Resour., 131, 206, 1989. Perret, F.A., The eruption of Mount Pelee, 1929-1932, Camegie Inst. Washinglon Publ., 458, 1937.

Rose, W.I., Jr., Pattem and mechanism of volcanic activity at the Santiaguito volcanic dome, Guatemala, Bull. Volcanol., 37, 73-94, 1973.

Rose, W.1., Jr., Volcanic activity at Santiaguito Volcano, Guatemala, 1976 1984, in The Emplacement of Silicic Domes and Lava Flows, edited by J. H. Fink, Spec. Pap. Geol. Soc. Am., 212, 17-28, 1987.

Rose, W.I., Jr., T. Pearson, and S. Bonis, Nuee ardente eruption from the foot of a dacite flow, Santiaguito Volcano, Guatemala, Bull. Volcanol., 40, 53$70,1977$.

Rose, W.1., Jr., R.L. Chuan, W.F. Giggenbach, P.R. Kyle, and R. B. Symonds, Rates of sulfur dioxide and particle emissions from White Island volcano, New Zealand, and an estimate of the total flux of major gaseous species, Bull. Volcanol., 48, 181-188, 1986.

Scot, W.E., Holocene thyodacite eruptions on the flanks of South Sister Volcano, Oregon, in The Emplacement of Silicic Domes and Lava Flows, edited by J.H. Fink, Spec. Pap. Geol. Soc. Am., 212, 35-53, 1987.

Self, S., J. Kienle, and J.-P. Huot, Ukinrek Maars, Alaska, II, Deposits and formation of the 1977 craters, J. Volcand. Geotherm. Res., 7, 39-65, 1980. Sparks, R.S.J., The dynamics of bubble formation and growth in magmas: A review and analysis, J. Volcanol. Geotherm. Res., 3, 1-37, 1978.

Swanson, D.A. and R.T. Holcomb, Regularities in growth of the Mount St. Helens dacite dome, 1980-1986, in Lava Flows and Domes: Emplacement Mechanisms and Hazard Implications, edited by J.H. Fink, International Association of Volcanology and Chemistry of the Earth's Interior Proc. Volcanol., 2, 1-24, 1990.

Swanson, D.A., D. Dzuris in, R.T. Holcomb, E.Y. I watsubo, W.W. Chadwick, Jr., T.J. Casadevall, J.W. Ewert, and C.C. Heliker, Growth of the lava dome at Mount St. Helens, Washington, in Emplacement of Silicic Domes and Lava Flows, edited by J.H. Fink, Spec. Pap. Geol. Soc Am., 212, 1-16, 1987. Swanson, S.E., M.T. Naney, H.R. Westrich, and J.C. Eichelberger, Crystallization history of Obsidian Dome, Inyo domes, Califomia, Bull. Volcanol., 51, 161-176, 1989.

Taylor, B.E., Magmatic volatiles: Isotopic variations of $\mathrm{C}, \mathrm{H}$, and S, Mineral. Soc. Am. Rev. Mineral., 16, 185-226, 1986.
Taylor, B.E., J.C. Eichelberger, and H.R. Westrich, Hydrogen isotopic evidence of hyolitic degassing during shallow intrusion and eruption, Nature, 306, 541-545, 1983.

Taylor, G.A., The 1951 eruption of Mount Lamington, Papua, Bull.Aust. Bur. Miner. Resowr., 38, 1-129, 1958.

Watanabe, H., Gradual bubble growth in dacite magma as a possible cause of the 1977-1978 long-lived activity of Usu Volcano, J. Volcanol. Geotherm. Res., 20, 133-144, 1984.

Westrich, H.R., and J.C. Eichelberger, Obsidian lava: a permeable foam eruption model (abstract), in Continental Magmatism, IAVCEl Gen. Assembly Abstracts, Bull. N. M. Bur. Mines Min. Resour., 131, 291, 1989.

Westrich, H.R., H.W. Stockman, and J.C. Eichelberger, Degassing of thyolitic magma during ascent and emplacement, J. Geophys. Res., 93, 6503$6511,1988$.

Williams, S.N., and S. Self, The October 1902 Plinian eruptions of Santa Maria Volcano, Guatemala, J. Volcanol. Geotherm. Res., 16, 33-56, 1983.

Wilson, L., R.S.J. Sparks, and G.P.L. Walker, Explosive volcanic eruptions, IV. The control of magma propenies and conduit geometry on eruption column behavior, Geophys. J. R. Astron. Soc., 63, 117-148, 1980.

Wolff, J.A., Welded-tuff dykes, conduit closure, and lava dome growth at the end of explosive eruptions, J. Volcanol. Geotherm. Res., 28, 279-284, 1986.

Wright, J.V., and G.P.L. Walker, The ignimbrite source problem: Significance of a co-ignimbrite lag-fall deposit, Geology, 5, 729-732, 1977.

Yokoyama, I., H. Yamashita, H. Watanabe, and H. Okada, Geophysical characteristics of dacite volcanism-The 1977-1978 eruption of Usu Volcano, J. Volcanol. Geotherm. Res., 9, 335-358, 1981.

Zen, M.T., Destruction, formation, and growh of the Merapi domes, Buletin Jurusan Geologi, 14, 7-13, 1985.

S.W. Anderson, Department of Mathernatics, Physical Science, and Technology, Black Hills State University, Spearfish, SD 57799.

J.H. Fink and C.R. Manley, Department of Geology, Arizona State University, Tempe, AZ 85287-1404.

(Received July 31, 1991;

revised January 24,1992 ;

accepted February 18, 1992.) 